\title{
Effects of Water Pipe Leaks on Water Quality and on Non- Revenue Water: Case of Arusha Municipality
}

\author{
Josephat Alexander Saria \\ The Faculty of Science, Technology and Environmental Studies, The Open University of Tanzania, Dar es Salaam, Tanzania
}

\section{Email address:}

josephat.saria@out.ac.tz

\section{To cite this article:}

Josephat Alexander Saria. Effects of Water Pipe Leaks on Water Quality and on Non-revenue Water: Case of Arusha Municipality. Journal of Water Resources and Ocean Science. Vol. 4, No. 6, 2015, pp. 86-91. doi: 10.11648/j.wros.20150406.12

\begin{abstract}
Utilities can no longer tolerate inefficiencies in water distribution systems and the resulting loss of revenue associated with underground water system leakage. Increases in pumping, treatment and operational costs make these losses prohibitive. Chronic water losses have been the hallmark of Tanzania especially AUWSA water management over the decades. The aim of this research was to assess effects of water pipe leaks on water quality and on non revenue water. Out of 140 respondents it was found out that unauthorized connections (illegal and by pass) account to $24 \%$, while $30 \%$ of respondents identified leakages from water system (transmission mains, distribution mains, utility's reservoirs, service connections); $16 \%$ due to stopped/malfunctions water meters (Bulk and customer water meters), whilst $14 \%$ respondents enumerated that is caused by other reasons like corruption and bribery among meter readers. The combination of both leakage and low pressure is a source of contamination of pipe water because it allows contaminants to siphon into the water system hence bacterial contamination (TC averaged to $67.5 \mathrm{CFU} / 100 \mathrm{ml}$ and $\mathrm{FC}$ averaged to $4.0 \mathrm{CFU} / 100 \mathrm{ml}$ while $\mathrm{pH}$ range from $6.5-7.7$ ). Community awareness programmes about NRW to all consumers must be conducted to ensure that customer confidence in the utility's services is maintained. A key element in this is open communication like public should be able to easily contact the utility to report burst pipes, leakages, or other concerns.
\end{abstract}

Keywords: Non Revenue Water, EWURA, Faecal Coliform, AUWSA, Arusha

\section{Introduction}

Improving access to water supply and sanitation services (WSS) has been an issue on the development agenda to most of developing countries and still these services does not reach a significant proportion of the world's population. Every year, this becomes more of a challenge due to factors such as rapid population growth and increasing urbanization [1]. Water supply and sanitation in Tanzania is characterized by low levels of access, in particular in urban slums and in rural areas, as well as poor service quality in the form of irregular water supply [2,3]. Determining data on access is difficult because different definitions and sources are used, which results in significant discrepancies. According to a report, household surveys regularly return lower rural water supply coverage than estimates by the Ministry of Water (which is collected by district water engineers and urban water and sanitation authorities). For urban areas, survey data are consistently higher because they also include households that are not connected to the formal water supply network and access water from neighbors, protected wells or boreholes [4].

Rapid population growth and urbanization in Tanzania exerts enormous pressure on the delivery of water supply and sanitation services to her citizens [5]. Since Tanzania is not in a position to meet the costs of maintaining and improving water supply and sanitation services from public revenues, this has led to the introduction of a commercial approach to the provision of these services on which they must be paid for, rather than a free right. Regulation of water supply and sanitation services is particularly important since water entities which provide water supply and sanitation services do not face competitive pressures that would otherwise ensure the quality of service provision to consumers is adequate.

Water quality and the Non-Revenue Water (NRW) are the big challenges to the water industry in general and it openly affects the level of income realized from water billings, service level and consumer satisfaction to meet the water demand from consumers which in turn affects service sustainability in water sector [6]. One of the major issues 
affecting water utilities in the developing world is the considerable difference between the amount of water put into the distribution system and the amount of water billed to consumers. High levels of NRW reflect huge volumes of water being lost through leaks, not being invoiced to customers, or both [6].

A lack of understanding of the magnitude and sources of NRW is one of the main reasons for insufficient NRW reduction efforts around the world. Only by quantifying NRW and its components and calculating appropriate performance indicators can the NRW situation be properly understood, cost estimates be made, and a fair contract model be developed $[7,8,9]$. It is also of utmost importance to have good pressure and supply time data, as those have a fundamental impact on leakage levels and its reduction/increase potential.

The existence of NRW is contributed by a number of reasons, depending on the technological development level and its purpose in the industry [7]. The developed countries have managed to control the level of NRW to the lower level like Singapore with 5\% and Vitens in the Netherlands with $6 \%$ and below, while the developing countries including Tanzania with an average of $35.2 \%$ of NRW for regional UWSAs [8]. In Tanzania, for instance the suggested level is $20 \%$ or below as per the regulator's (EWURA), but none of the water Authorities has ever met that level [7]. This research aims to examine the factors causing Non-Revenue Water (NRW) in Arusha Urban Water supply and Sewerage Authority (AUWSA) as well as quality of pipe water supplied in Arusha city.

It is the intention of this study to determine the knowledge and understanding of NRW for Arusha Urban Water Supply Authority management in relation with poor management system, equity and quality of potable water supply in rapid growth of city like Arusha Municipality. We intend to develop strategy for management of non revenue water (NRW) to gain a better understanding of the reasons for NRW and the factors which influence its components. Then techniques and procedures can be developed and tailored to the specific characteristics of the network and local influencing factors, to tackle each of the components in order of priority. This diagnostic approach, followed by the practical implementation of solutions which are practicable and achievable, can be applied to any water company, anywhere in the world, to develop a strategy for NRW management.

\section{Methodology}

\subsection{Description of Arusha City}

Arusha City is located between $2^{\circ}$ and $6^{\circ} \mathrm{S}$ as well as longitude $34.5^{\circ}$ and $38^{\circ} \mathrm{E}$. The City is also located on the southern slopes of Mount Meru lying at a height between $1160 \mathrm{~m}$ to $1450 \mathrm{~m}$ above sea level (Figure 1). It lies on the Great North road at the center between Cairo and Cape Town. Arusha City is an industrial, international trading, tourism and conference centre. Arusha City Council has a population of 416,442 (199,524 male and 216,918 female) [5].

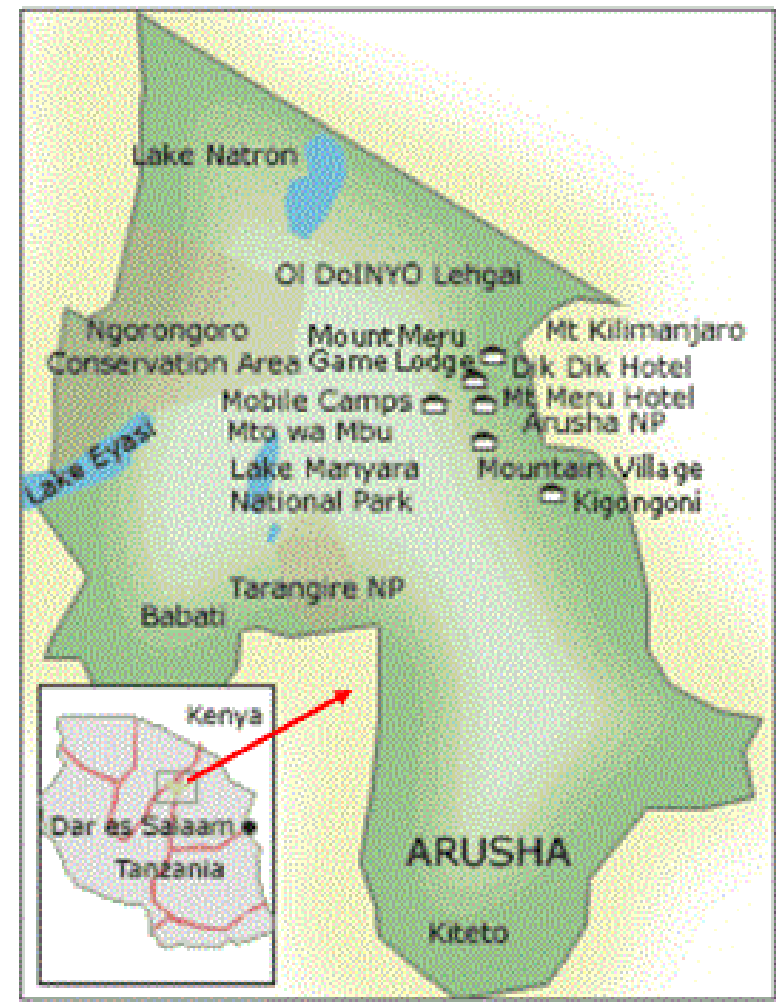

Figure 1. A Map of Study Site: Tanzania Locating Arusha City.

\subsection{Population and Sampling Procedures}

Multistage sampling technique was used to select, one hundred and forty (140) respondents. Questionnaires were distributed to some of AUWSA employees (Management team, Assistants/Supervisors, Technicians/Meter Readers, Normal staff) and customers of different categories (Domestic, Commercial, Industrial and Parastatal). The choice of these units of inquiry is made basing on their involvement, knowledge, experience and number of years stayed in AUWSA. Out of 140 people 21 (15\%) were interviewed and $119(85 \%)$ responded through questionnaire as shown in Table 1.

Table 1. Sampling Frame.

\begin{tabular}{|c|c|c|c|c|}
\hline \multirow{2}{*}{$\begin{array}{l}\text { Unity of Inquiry } \\
\text { AUWSA } \\
\text { Employees } \\
\end{array}$} & \multicolumn{3}{|l|}{ Sample Size } & \multirow[b]{2}{*}{$\begin{array}{l}\text { Percent } \\
\text { (\%) }\end{array}$} \\
\hline & Questionnaires & $\begin{array}{l}\text { Intervie } \\
\text { wed }\end{array}$ & Total & \\
\hline Management team & 6 & 0 & 6 & 100 \\
\hline $\begin{array}{l}\text { Assistants/Supervis } \\
\text { ors }\end{array}$ & 6 & 0 & 6 & 100 \\
\hline $\begin{array}{l}\text { Technicians/Meter } \\
\text { Readers }\end{array}$ & 10 & 5 & 15 & 100 \\
\hline Normal staff & 35 & 8 & 43 & 100 \\
\hline Domestic & 46 & 6 & 52 & 87 \\
\hline Parastatal & 6 & 2 & 8 & 80 \\
\hline Institutions & 5 & 0 & 5 & 100 \\
\hline Industrial & 5 & 0 & 5 & 100 \\
\hline Total & 119 & 21 & 140 & 89 \\
\hline
\end{tabular}


The main tools for data collection were review of relevant literature, household survey with a structured questionnaire, semi-structured interviews with key informants within the study areas. Data analysis was carried out using the Statistical Package for Social Sciences (SPSS version 16.0) as well as content analysis for qualitative data.

\subsection{Microbiological Analysis}

Total and Faecal bacteria were analysed using membrane techniques as described in American Health Public Association [10] whereby $100 \mathrm{ml}$ of undiluted and diluted (1 - 10 times) water sample were filtered through $0.45 \mu \mathrm{m}$ pore size membrane filters. The filters were transferred to two selective media where FC was grown on m-FC broth and TC was grown on m-Endo broth. Plates for Faecal coliform (FC) bacteria were incubated at $44.5 \pm 0.5 \mathrm{C}^{\mathrm{o}}$ for $24 \mathrm{hrs}$. FC colonies appeared blue while plates for total coliform (TC) bacteria incubated at $37 \pm 0.5 \mathrm{C}^{\circ}$ for 24 hours were reddish in color. Environmental parameter $(\mathrm{pH})$, were measured in situ at each station using a multi-parameter water quality checker (HoribaU-10, Japan).

\section{Results and Discussion}

In this development water authorities faced a number of challenges like water production which does not meet demand and old infrastructures resulting to water losses that lessen financial capability of the water utilities hence poor services. For many years, the most widely used performance indicators in the World and Tanzania is not exception for Non-Revenue Water and Real (Physical) losses have been percentages loss. Water produced and delivered to the distribution system is intended to be sold to the customer not lost from the distribution system without authorization [11]. When required to identify the main causes of Non-Revenue Water in Arusha Urban Water Supply and Sewerage Authority, the results for respondents are as shown on the figure 2 .

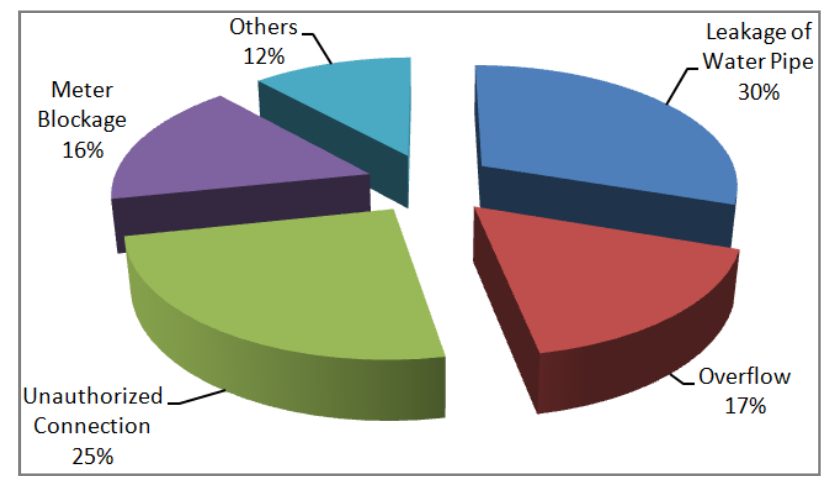

Figure 2. Reasons for an Increase in Non Revenue Water

\subsection{Water Leakage}

Physical losses can occur along the entire distribution system, from storage reservoirs and the primary network to the smallest service connections. Sometimes, when people think about leakage, they normally think of big and spectacular pipe bursts. These often cause a lot of damage but are insignificant in volume compared to all the other leaks that do not come to the surface.

In Arusha municipality leakage of water pipes is estimated to be around $30 \%$ [12]. When management were interviewed they identified it is due to different reasons including old and poorly constructed pipelines, inadequate corrosion protection, poorly maintained valves, mechanical break and high pressure (Figure 3).

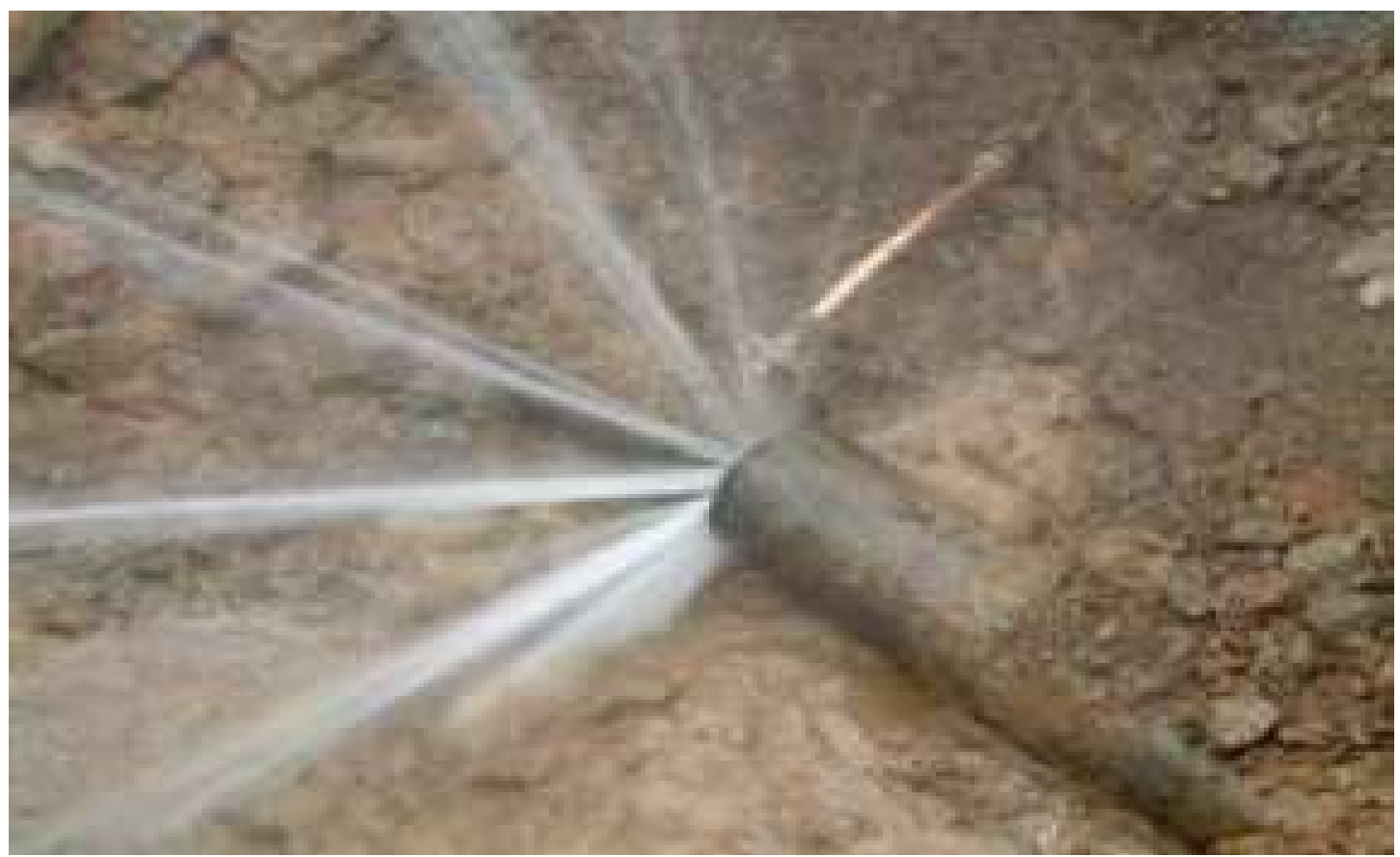

Figure 3. Pipe Bust Due to High Pressure in the Water System. 
Figure 2 revealed that, $24 \%$ of respondents pointed out that the main causes of NRW in Arusha Water Supply and Sewerage Authority was caused by unauthorized connections (illegal and by pass); $30 \%$ of respondents pointed out that NRW in AUWSA was caused by leakages from water system due to age of the water supply system (Figure 4).

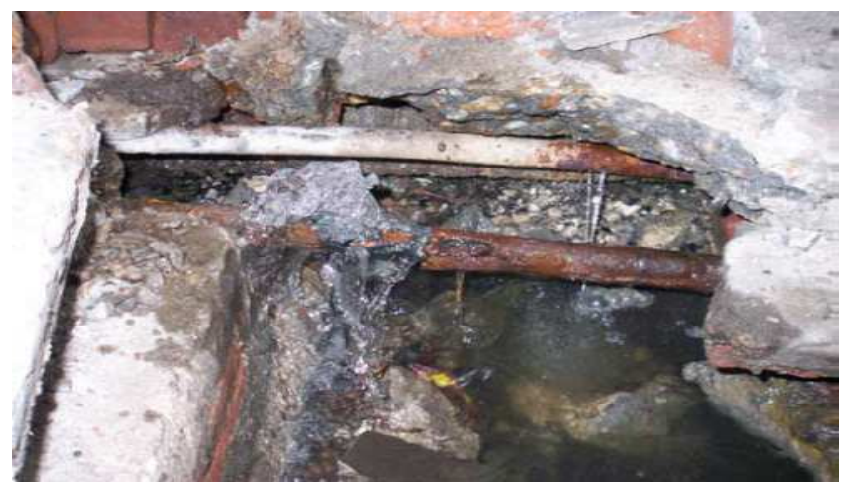

Figure 4. Aged Water Pipe Broken.

About $16 \%$ of respondents mentioned that the causes of water losses caused by stopped/unfunction water meters (bulk and customer water meters), whilst 14\% respondents enumerated that non- revenue water was caused by other reasons like corruption and bribery among meter readers, wrong data capturing, improper customers records, water meter reversal, wrong water meter installations and unread water meters) and $16 \%$ of respondents mentioned that NRW was caused by overflow from storage tanks and break pressure tanks.

The most commonly used indicator to measure NRW is the percentage of NRW as a share of water produced. When losses in terms of absolute volume are constant the percentage of NRW varies greatly with total water use, i.e. if water use increases and the volume of losses remains constant the percentage of NRW declines. This problem can be eliminated by measuring NRW not as a share, but in terms of absolute losses per connection per day, as recommended by other researchers [9]. Nevertheless, the use of percentage figures to compare levels of NRW remains common despite its shortcomings. Losses per kilometer of network are more appropriate to benchmark real losses, while losses per connection are more appropriate to benchmark apparent losses. On average, Arusha WSSA continued to have the highest NRW ( $\mathrm{m}^{3}$ lost per km per day) which was $60.2 \mathrm{~m}^{3}$ of water per day in a kilometer length of the distribution network. Previously in 2011/12, Arusha WSSA had the highest volume of $54.48 \mathrm{~m}^{3}$ of water lost per $\mathrm{km}$ per day (Figure 5).

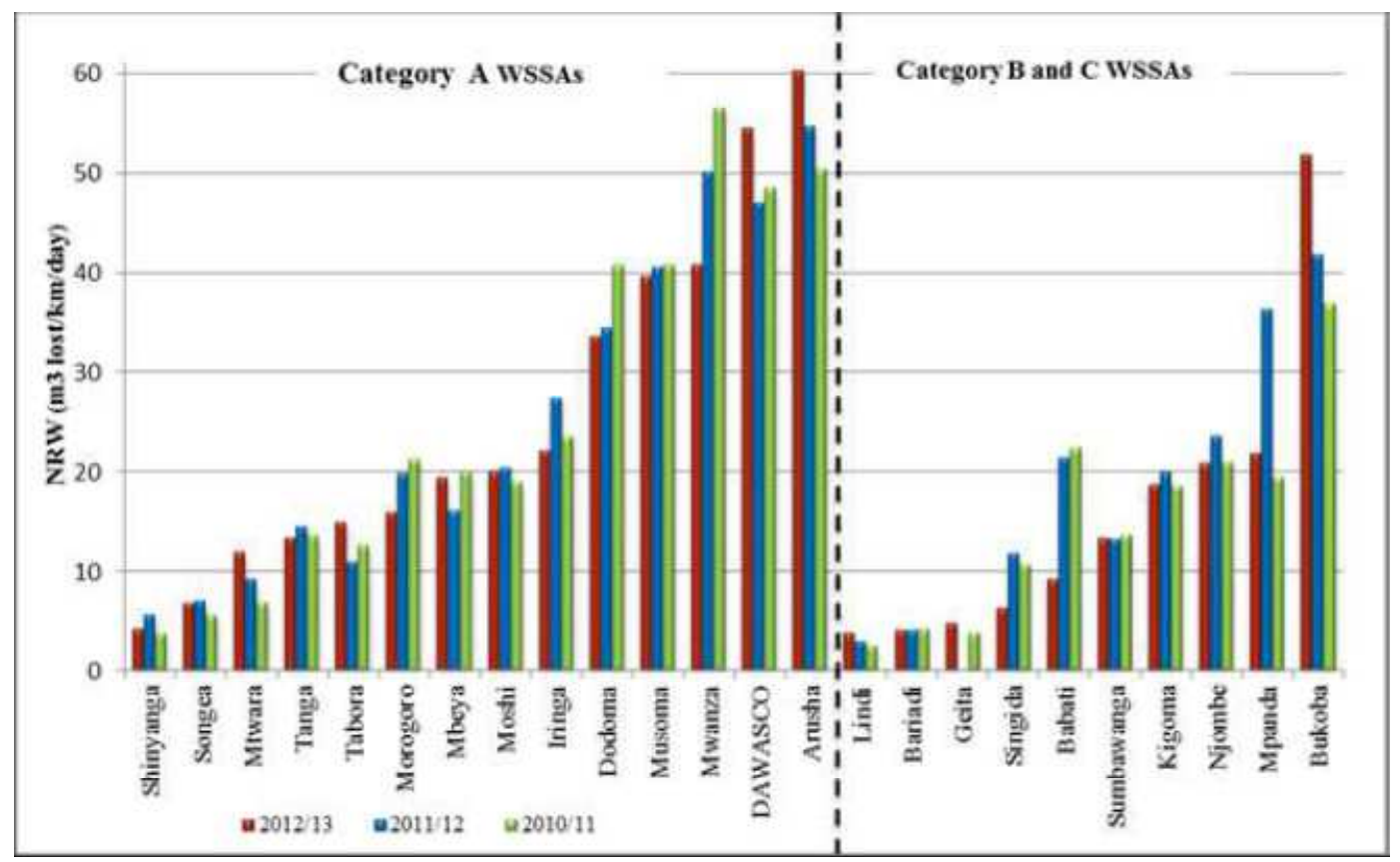

Figure 5. NRW Measured in a Kilometer Length of the Pipe Network in One Day [7].

Apart from Arusha Municipality having high volume of water lost per kilometer in a day, also Arusha WSSA continued to have the highest water connection density in a kilometer of the water distribution network with 132 connections per kilometer of water distribution network. Meanwhile, Lindi WSSA remained with the lowest reported water connections density of 15 connections per kilometer. All these are the big source of NRW.

\subsection{Unhygienic Water Supply}

Non Revenue Water gives negative impact on the quality of the national water supply services. It reflects the problem of instability of water supply infrastructure. Damaged pipes network, water supply interruption to the consumers and quality of treated water supplied are among the subject that shall be given attention in ensuring high quality of water 
supply service.

The water runs through AUWSA pipe network is generally of poor quality not only with regards to taste, smell, appearance and temperature but also from a public health point of view. The last is the worst, the consumer can be misled, because the water can look clean and taste pleasant and yet still contain pathogenic microorganisms. In the interview with AUWSA officials they indicated

"...the main pipelines have been installed in phases parallel with development of water works and matched with the past consumer patterns in the different areas of Arusha city, without regard to the development prognosis".

This was inline with other study [13] which indicated many of the main pipelines in the developing countries city today are of wrong dimensions causing many areas to suffer from high pressure, too low or completely lack of water pressure. The combination of both leakage and low pressure is a source of contamination of pipe water because it allows contaminants to siphon into the water system hence bacterial contamination (Table 2).

Table 2. Analysis of Tape Water Samples $(N=10)$.

\begin{tabular}{llll}
\hline Sampling Site & T.C. CFU/100ml & F.C. CFU/100ml & pH \\
\hline Njiro & 74 & 05 & $6.7-7.2$ \\
Naura & 61 & 03 & $6.5-7.7$ \\
\hline
\end{tabular}

The responses showed that water from the taps is seen dirty (muddy) when there is a burst or broken pipe which creates a leakage somewhere in the network allowing mud to get into the network (Figure 6). Sometimes mud is seen in the taps when there is a new water connection made somewhere in the neighbourhood.

The highest number of respondents more than $60 \%$ indicated that they have seen rubbishes like charcoal, muddy and sand coming from their pipes.

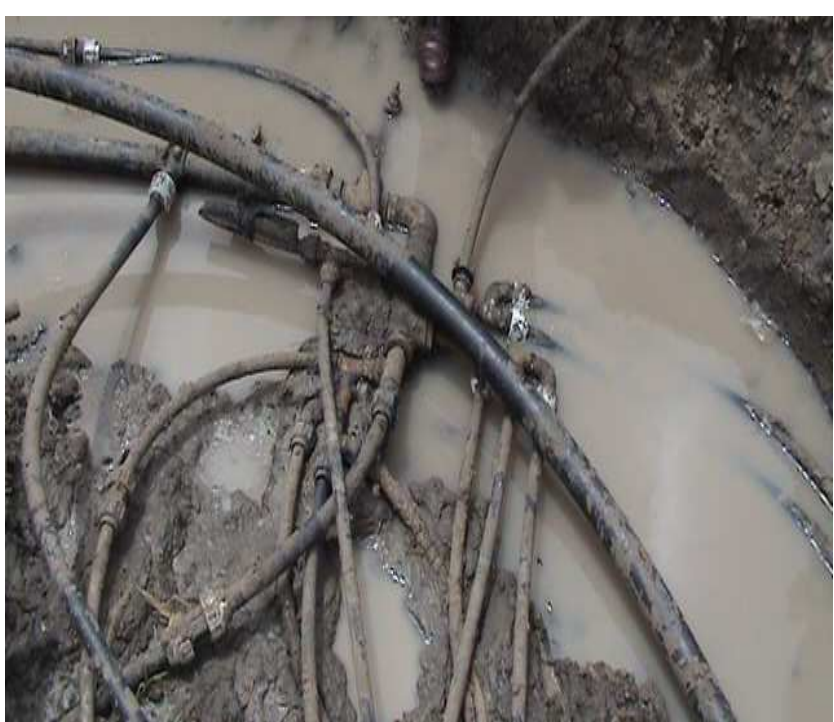

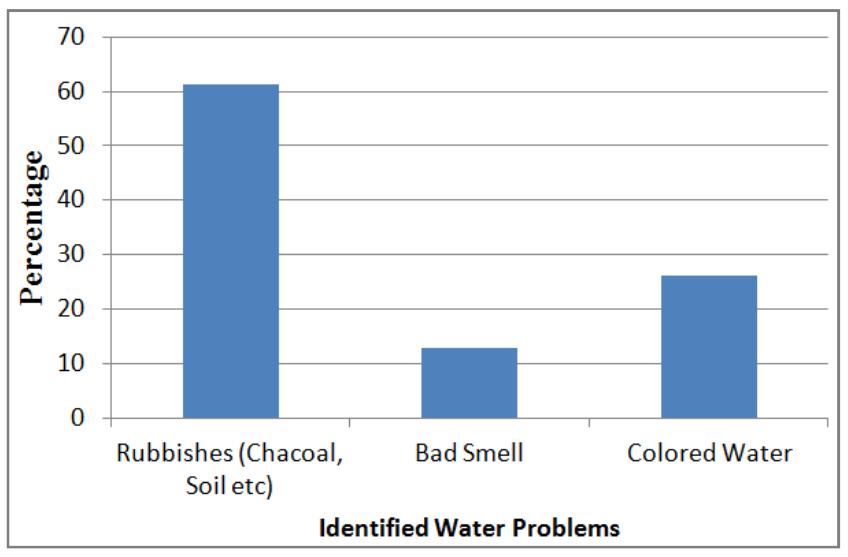

Figure 6. Issues Identified by Customers on the Quality of Water:

\subsection{Unauthorized Connection and Meter by-Passing}

The urban poor are often blamed for high levels of NRW, especially due to illegal connections. On the other hand, the poor are significantly affected by high water losses. While theft of water in low-income communities is certainly a reality in many African cities, its impact must be put in the proper perspective. Poor connections and meter bypassing (Figure 7) has been a major issue of concern and is implicated a significant number of the corporation's staff involved in helping customers to carry out illegal consumption in form of meter bypasses, meter tempering/reversal and under-reading. In addition, the corporation uses a set of forgiveness calls for both its employees and customers to, willingly, disclose illegal consumption. In one of the branches where illegal consumption was uncontrolled, more than $20 \%$ of the customer accounts were voluntarily surrendered as suspected illegal connections by staff $[11,14]$.

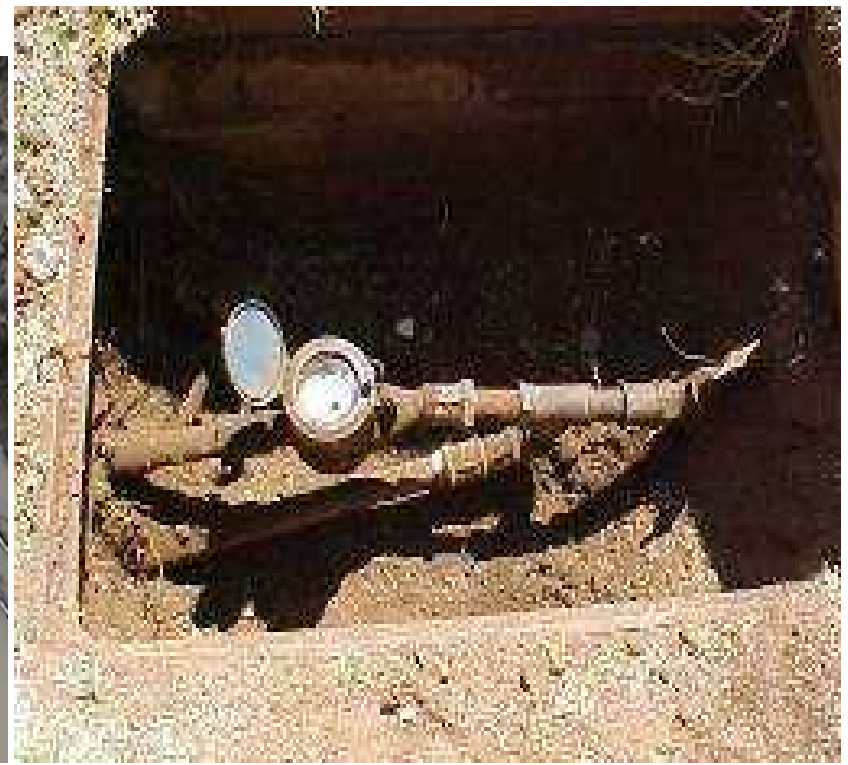

Figure 7. Poor Connections and Meter By-Passing. 
In the discussion with AUWSAs management and the Annual reports the number of unauthorized connections increased from 129 during financial year 2009/2010 to 304 . All these seem to be a big issue in having high NRW in Arusha Municipality.

\section{Conclusion}

Community awareness programmes about NRW to all consumers must be conducted to ensure that customer confidence in the utility's services is maintained. A key element in this is open communication. For example, the public should be able to easily contact the utility to report burst pipes, leakages, or other concerns. Water customers must be sensitized by the AUWSA on the water loss on the supply network. It was discovered that AUWSA conduct very few water customer awareness meeting and the few meetings are conducted to very few customers during the National Annual Water Week starting from $16^{\text {th }}$ to $22^{\text {nd }}$ March of every year which is not enough.

\section{Acknowledge}

The author is extending his acknowledgements to the Arusha Water Supply and Sewerage Authority Management team, DAWASCO management as well as Arusha city water customers who participated in this study and all those who participated in one way or another. Also I would like to extend my acknowledgement to Dr G. F. Mhando (MD) who has being constantly encouraging me to study about bacterial contamination due to wide spread of cholera in Tanzania.

\section{References}

[1] United Nations (2003), The UN World Water Development Report - Water for People, UNESCO and Berghan Books, Barcelona.

[2] WHO (2003), The Global Water Supply and Sani4tation Assessment 2000 [http://www.who.int/docstore/water_sanitation_health/Globass essment/GlobalTOC.htm], (accessed on 04/08/14).
[3] Thompson, J.; Porras, I.T.; Wood, E.; Tumewine, J.K.; Mujiwahuzi, M.R.; Katui -Katua, M. And Johnstone, N. (2000), Waiting at the Tap: Changes in Urban Water use in East Africa Over Three Decades, Environment and Urbanization, 12(2) 37-52.

[4] Mukoyogo, S. M. (1987), Planning and Budgeting for O\&M of Rural Water Supplies, Seminar, Regional and District Water Committees.

[5] URT (2012), National Bureau of Statistics, Ministry of Finance, Tanzania in Figures, htt/www.nbs.go.tz .

[6] Farley, M. and Trow, S. (2003), Losses in Water Distribution Networks, IWA Publishing.

[7] URT (2013a), EWURA, Water Review Report 2012/13.

[8] URT (2013b), Arusha Urban Water Supply and Sewerage Authority (AUWSA) (2013), Status of Water Supply and Waste Water Disposal Services in Arusha City, Arusha, Tanzania.

[9] Lambert, A. (2001), What do we know about Pressure: Leakage Relationships in Water Distribution Systems? IWA Conference System Approach to Leakage Control and Water Distribution Systems Management, Brno, Czech Republic.

[10] APHA, (2005), Standard Methods for the Examination of Water and Wastewater, 18th Ed., American Public Health Association (APHA), American Water Works Association (AWWA) and Water Pollution Control Federation (WPCF), Washington, D.C.

[11] Farley M., Wyeth G., Ghazali Z.B.M., Istandar A., and Signh S. (2008), The Manager's Non-Revenue Water Handbook, A Guide to Understanding Water Losses.

[12] AUWSA (2013), Non Revenue Water Management Project for AUWSA - Arusha Urban Water Supply and Sewerage Authority.

[13] Thornton, J., Shaw, M., Aguiar, M. and Liemberger, R. (2005), "How Low Can You Go? A Practical Approach to Pressure Control in Low Pressure Systems," Conference Proceedings, IWA Leakage 2005 Conference in Halifax, Nova Scotia, Canada.

[14] Kingdom, B., Liemberger, R. and Marin, P. (2006), The Challenge of Reducing Non-Revenue Water in Developing Countries-How the Private Sector Can Help: A Look at Performance-Based Service Contracting, World Bank, Paper No. 8, Dec 2006. 